\title{
In vitro EFFECTIVENESS OF AN AQUEOUS EXTRACT OF NEEM (Azadirachta indica A. Juss) LEAVES ON BACTERIA CAUSING HEALTHCARE ASSOCIATED INFECTION IN VALLEDUPAR
}

\author{
EFECTIVIDAD in vitro DEL EXTRACTO DE HOJAS DE NEEM (Azadirachta indica A. Juss) \\ SOBRE BACTERIAS CAUSANTES DE INFECCIÓNES ASOCIADAS A LA ATENCIÓN \\ SANITARIA EN VALLEDUPAR
}

\author{
Hedilka JIMÉNEZ RIOS ${ }^{1 \circledR}$, Bertilda PEDRAZA CLAROS ${ }^{2}{ }^{\circledR}$, Aslenis MELO RIOS ${ }^{3(\mathbb{D}}$, \\ Jeraldin CASTRILLÓN MEJIA ${ }^{4}{ }^{\circledR}$, Ailyn FUENTES ARIAS ${ }^{5(}$
}

Received: 24 February 2020 Approved: 08 December 2020

\begin{abstract}
Background: Globally, the need to address strategies for preventing infections associated with health care has increased worldwide. In the city of Valledupar, Colombia, reports of bacteria resistant to chemical or enzymatic biocides in hospital environments and surfaces are increasingly frequent, evidencing the importance of conducting studies aimed at identifying alternative active ingredients for disinfectant products. Objective: Evaluate the in vitro effectiveness of Neem leaves extract over bacteria strains isolated from different areas and surfaces of a health institution in Valledupar, compared to disinfectants for hospital use, an enzymatic detergent, and a commercial chemical disinfectant. Methods: Biocidal activities on bacteria isolated from hospital surfaces, such as Acinetobacter baumanni, Bacillus subtilis, Enterobacter aerogenes, Staphylococcus aureus, Staphylococcus epidermidis, Micrococcus sp, and Stenotrophomonas maltophilia were analyzed. The Neem leaves extract was evaluated at concentrations of 3, 4, and $5 \%$ for each bacterium during 15-minute contact time, incubated at $37^{\circ} \mathrm{C}$ for 18 hours. We compared two antimicrobial chemicals, a disinfectant (based on formaldehyde, cetrimide, and glutaraldehyde), and an enzymatic detergent (based on protease, lipase, and amylase). Results: The aqueous Neem extract did not show significant differences with the other treatments with 99.48 to $100 \%$ inhibition against bacteria of the species Acinetobacter baumanni, Enterobacter aerogenes, Staphylococcus aureus, and Micrococcus sp.; Bacillus subtilis, and Stenotrophomonas maltophilia strains were the most resistant strains inhibited by enzymatic detergent and disinfectant, respectively. None of the products evaluated were effective against all in vitro strains. Conclusions: These data show Neem's bacteriostatic properties, its potential in in-hospital products and the need to combine different active ingredients in a disinfection plan.

Keywords: antimicrobial, Neem Tree, cross infection Acinetobacter baumanni, Staphylococcus epidermidis

Magister en educación. Universidad de Santander. Facultad Ciencias de la Salud, Grupo de Investigación CIENCIAUDES. Valledupar, Colombia.

2 Magister en Ciencia y Tecnología de Alimentos. Universidad de Santander. Facultad Ciencias de la Salud, Grupo de Investigación CIENCIAUDES. Valledupar, Colombia.

3 Magister en gestión y auditorías ambientales. Universidad de Santander. Facultad Ciencias de la Salud, Grupo de Investigación CIENCIAUDES. Valledupar, Colombia.

Bacterióloga. Universidad de Santander. Facultad Ciencias de la Salud, Grupo de Investigación CIENCIAUDES. Valledupar, Colombia.

Bacterióloga. Universidad de Santander. Facultad Ciencias de la Salud, Grupo de Investigación CIENCIAUDES. Valledupar, Colombia.

Corresponding author: asl.melo@mail.udes.edu.co
\end{abstract}




\section{RESUMEN}

Antecedentes: A nivel mundial ha aumentado la necesidad de abordar estrategias para la prevención de infecciones asociadas a la atención de salud. En la ciudad de Valledupar, Colombia, cada vez son más frecuentes los reportes de bacterias resistentes a biocidas químicos o enzimáticos, en ambientes y superficies hospitalarias, lo cual evidencia la importancia de realizar estudios orientados a la identificación de principios activos alternativos para productos desinfectantes. Objetivo: Evaluar la efectividad in vitro del extracto de hojas de Neem en cepas de bacterias aisladas en diferentes áreas y superficies de una institución de salud en Valledupar, en comparación con desinfectantes de uso hospitalario, un detergente enzimático y un desinfectante químico comercial. Métodos: Se analizó la actividad biocida sobre las bacterias aisladas de superficies hospitalarias Acinetobacter baumanni, Bacillus subtilis, Enterobacter aerogenes, Staphylococcus aureus, Staphylococcus epidermidis, Micrococcus sp, y Stenotrophomonas maltophilia. El extracto de hojas de Neem se evaluó a concentraciones de 3, 4 y 5\% para cada bacteria durante un tiempo de contacto de 15 minutos, incubados a $37^{\circ} \mathrm{C}$ durante 18 horas. Se comparó dos productos químicos antimicrobianos, un desinfectante (a base de formaldehído, cetrimide y glutaraldehído), y un detergente enzimático (a base de Proteasa, Lipasa y amilasa). Resultados: El extracto acuoso de Neem no presentó diferencias significativas con los demás tratamientos con inhibición del 99,48 al 100\%, sobre bacterias de las especies Acinetobacter baumanni, Enterobacter aerogenes, Staphylococcus aureus y Micrococcus sp; las cepas Bacillus subtilis y Stenotrophomonas maltophilia fueron las más resistentes a ser inhibidas por el detergente enzimático y el desinfectante, respectivamente. Ninguno de los productos evaluados fue efectivo contra todas las cepas in vitro. Conclusiones: Estos datos evidencian las propiedades bacteriostáticas del Neem, su potencial en productos de uso intrahospitalario y la necesidad de combinar diferentes principios activos en un plan de desinfección.

Palabras claves: Antibacteriano, Infección hospitalaria, Neem, Acinetobacter baumanni, Staphylococcus epidermidis

\section{INTRODUCTION}

According to the Pan American Health Organization (PAHO) and World Health Organization (WHO), approximately 1.4 million people acquire a Health care Associated Infection (HAIs), affecting 1 of 20 hospitalized patients, affecting about 4.1 million patients, and approximately 37,000 patients die each year (1). Furthermore, the Acinetobacter baumannii complex is the most frequently isolated pathogen with $80 \%$ of all clinical isolates and has a potential resistance of $3.1 \%$ to carbapenems (2).

These cases have become the most frequent events in health care, affecting several patients annually in many countries of the world, generating an impact on the quality of life of patients. The economic expenses attributable to them estimated for the US a cost of care of 28 and 33 billion dollars a year (3).

In Colombia, the cost of care for HAIs is COP $1,190,879$ per person, in antibiotic treatment (41\% of the total value) and laboratory analysis (13.5\%) (4). Specifically, there are records of the presence in the hospital facilities of bacteria resistant to bactericides in Valledupar. $50 \%$ of S. aureus strains showed resistance to methicillin, up to $14 \%$ were isolated from the emergency and surgery areas (5).

The reason why the Ministry of Health and Social Protection of Colombia in 2018 created the prevention, surveillance, and control Program of HAIs and antimicrobial resistance, was to provide elements to strengthen the prevention and control of HAIs. Considering among other measures, the appropriate cleaning and disinfection practices, including the disinfectants selection for hospital use (1).

Consequently, using inside the disinfectant's composition natural ingredients with high biocidal power has been increasingly highlighted. Among those are extracts and essential oils of aromatic plants such as Cymbopogon citratus, Lippia alba (Mill), Eugenia caryophyllata (Thunb), Aloe vera (L.), Azadirachta indica (A. Juss), and others 
$(6,7)$. The last one is a meliaceous family plant, currently used in the pharmacopeia, cosmetics, and phytosanitary products. This plant has active natural substances in leaves and seeds against multiple pathogens, including bacteria, fungi, and viruses (8). Its extract has been demonstrated to contain relevant properties at the health level $(9,10)$, with antibacterial, anti-inflammatory, antiviral, hypoglycemic, and antiulcer activity, among others (11).

Furthermore, experimental studies indicate that the ethanol extract of leaves has antibacterial activity in vitro against Staphylococcus aureus (12). Specific structural components within the Neem extract, such as deacetylgedunin (DCG), presents a high level of coupling with the PLpro protein of SARSCoV-2, which allows its inhibition (13).

Balakrishna et al. (7) developed a hand sanitizer gel containing Azadirachta indica, Ocimum sanctum and Citrus limon extracts, with an inhibitory effect on bacteria related to HAIs Escherichia coli and Staphylococcus aureus.

This research raised the evaluation of the bacteriostatic effect of the extract of the leaves and seeds of the Neem tree against microorganisms' strains isolated from surfaces in procedure rooms, neonatal intermediate care unit, adult intermediate care unit, and surgery of a hospital institution in Valledupar.

\section{MATERIALS AND METHODS}

\section{Location}

The study was carried out in the laboratory of the University of Santander, in Valledupar, Colombia.

\section{Microorganisms}

The bacteria associated with IAAS, Acinetobacter baumanni, Bacillus subtilis, Enterobacter aerogenes, Staphylococcus aureus, Staphylococcus epidermidis, Micrococcus sp., and Stenotrophomonas maltophilia, were isolated by the method of a swab from different surfaces such as the surgical procedure room and the intensive care unit (ICU) (adult and neonates ICUs) from a hospital in Valledupar township. The bacteria grown at $37^{\circ} \mathrm{C}$ amid nutrient agar and Muller Hilton cultures. The strains were identified by the API 20E method for enterobacteria and API 20NE for other gram-negative bacilli. $0.85 \%$ saline suspensions were prepared on the Macfarland 0.5 scale to conduct the tests.

\section{Extract from A. indica (Neem)}

The aqueous Neem extract was prepared according to the methodology described by Barrabí and Garcia (14), where the plant material was manually collected in sterile plastic bags with airtight closure. Leaves and seeds were obtained from 10-year-old Neem trees located in the Centro Biotecnológico del Caribe (CBC)-SENA in Valledupar, Colombia, (169 MAMSL and an average temperature of $28^{\circ} \mathrm{C}$ ). The material was washed with distilled water, allowed to dry at $28^{\circ} \mathrm{C}$. Afterward, $5 \mathrm{~g}$ was weighed on a precision analytical balance, and $200 \mathrm{ml}$ of distilled water was added in a flask and boiled for 25 minutes. Finally, the mixture was filtered on filter paper in a Büchner funnel, and a final volume of $100 \mathrm{ml}$ of $5 \%$ Neem extract was obtained. Three concentrations were prepared from the stock solution: 3,4 , and 5\%.

\section{Chemical products}

This research evaluated the products frequently used to disinfect environments, instruments, and surfaces from the hospital. The first product corresponds to a pre-disinfectant enzymatic detergent (protease, lipase, and amylase; liquid presentation, $\mathrm{pH}$ 8.9) used for instrument cleaning. The second product is a microbial disinfectant based on formaldehyde, cetrimide, and glutaraldehyde (400, 600, and $1000 \mathrm{ppm}$ ).

\section{In vitro Effectiveness Comparison}

We prepared $9 \mathrm{ml}$ of the enzymatic detergent, the disinfectant, and Neem extract at 3, 4, and $5 \%$ concentrations. Afterward, $1 \mathrm{ml}$ of the microorganisms at 0.5 Macfarland scale was added, and let them mix during 15 minutes of contact. Finally, we inoculated the mix in-depth in plates containing $1 \mathrm{ml}$ of the Muller Hinton agar suspension and incubated at $37^{\circ} \mathrm{C}$. Each strain was assessed in triplicate. By calculating the percentage of dead cells: [1- (Mean CFU irrigant / Mean CFUinitial bacterial number)] $\times 100 \%$. Where "mean CFU irrigant" refers to the measurement of the colony-forming units resulting from exposure with the antimicrobial or irrigant substances to be evaluated and "Mean CFUinitial bacterial number", the measurement of the initial bacterial colony-forming units, before being in contact 
with antimicrobial substances (15). Likewise, the enzymatic detergent and disinfectant were used in concentrations of $3 \%$ and $100 \%$, respectively, assuming a high organic matter concentration. The density of application solutions is assumed to be 1 .

\section{Statistical analysis}

According to Tukey, the median of the results was compared by analysis of variance followed by a $5 \%$ post hoc test using the statistical software SPSS version 20.

\section{RESULTS}

In this research, when reviewing the results of the different treatments to which all the strains of bacteria evaluated were subjected, it was evidenced: 1) there was significant differences between extract of Neem concentrations and the bacterial strains evaluated 2) the efficiency of the disinfectant and growth inhibition bacterial, except in Bacillus subtilis strains (Table 1).

Table 1. In vitro inhibition of the aqueous extract of Neem leaves in the concentration 3, 4, and 5\%

\begin{tabular}{|l|c|c|c|c|c|c|c|}
\hline \multicolumn{1}{|c|}{ Treatment } & A. baumanii & B. subtilis & E. aerogenes & S. aureus & S. maltophilia & Micrococcus sp & S. epidermidis \\
\hline Neem 3\% & $99.84 \pm 0.04 \mathrm{~b}$ & $0.00 \pm 0.00 \mathrm{a}$ & $99.77 \pm 0.07 \mathrm{~d}$ & $99.87 \pm 0.05 \mathrm{e}$ & $0.00 \pm \pm 0.00 \mathrm{a}$ & $99.86 \pm 0.02 \mathrm{a}$ & $0.00 \pm 0.00 \mathrm{a}$ \\
\hline Neem 4\% & $99.95 \pm 0.01 \mathrm{~d}$ & $0.00 \pm 0.00 \mathrm{a}$ & $99.75 \pm 0.02 \mathrm{~d}$ & $99.85 \pm 0.02 \mathrm{~d}$ & $0.00 \pm 0.00 \mathrm{a}$ & $99.89 \pm 0.01 \mathrm{ab}$ & $0.00 \pm 0.00 \mathrm{a}$ \\
\hline Neem 5\% & $100.00 \pm 0.00 \mathrm{e}$ & $0.00 \pm 0.00 \mathrm{a}$ & $99.85 \pm 0.02 \mathrm{e}$ & $99.96 \pm 0.01 \mathrm{f}$ & $0.00 \pm 0.00 \mathrm{a}$ & $99.97 \pm 0.01 \mathrm{~d}$ & $0.00 \pm 0.00 \mathrm{a}$ \\
\hline Enzymatic detergent 3\% & $99.81 \pm 0.01 \mathrm{a}$ & $0.00 \pm 0.00 \mathrm{a}$ & $99.63 \pm 0.01 \mathrm{a}$ & $99.48 \pm 0.03 \mathrm{a}$ & $0.00 \pm 0.00 \mathrm{a}$ & $99.88 \pm 0.00 \mathrm{a}$ & $99.69 \pm 0.01 \mathrm{~b}$ \\
\hline Disinfectant 100\%. & $100.00 \pm 0.00 \mathrm{e}$ & $0.00 \pm 0.00 \mathrm{a}$ & $100.00 \pm 0.00 \mathrm{f}$ & $100.00 \pm 0.00 \mathrm{~g}$ & $99.91 \pm 0.01 \mathrm{e}$ & $100.00 \pm 0.00 \mathrm{~d}$ & $100.00 \pm 0.00 \mathrm{~b}$ \\
\hline
\end{tabular}

$\star$ According to Tukey 0.05 , the values in a column followed by the same letter do not differ significantly.

Additionally, it should be noted that the Neem extract was effective in inhibiting the growth of five out of seven bacteria under study, at all concentrations used, being greater in $5 \%$, at 15 minutes of contact, and without significant differences with the other treatments $(\mathrm{P}=0.00)$. In the case of bacteria Acinetobacter baumanii, Enterobacter aerogenes, Staphylococcus aureus, and Micrococcus sp., inhibitions of $99.48 \%$ were observed, while in the case of Bacillus subtilis, Stenotrophomonas maltophilia, and Staphylococcus epidermidis, no bactericidal effect was observed by the Neem extract.

The Bacillus subtilis and Stenotrophomonas maltophilia strains were the most resistants; Bacillus subtilis was also not susceptible to the enzymatic detergent nor the disinfectant. Stenotrophomonas maltophilia also presented resistance to enzymatic detergent.

\section{DISCUSSION}

This research indicated that using a single type of sanitizing product, applied for 15 minutes, is not efficient enough for reducing all bacteria genus that cause infections associated with health care, which were isolated from hospital's surfaces in the city of Valledupar. This finding highlights the importance of trials that allow the proper selection and suitable disinfectants use in hospital areas that facilitate the construction of a clear policy to prevent HAIs (16).

Furthermore, regarding the Bacillus subtilis resistance to disinfectants, it is associated with its characteristics as a sporulated microorganism, which forms a barrier that prevents the antimicrobial agents' entrance since the complex membranes that surround the endospore act as an additional penetration factor (17). Besides, an interference with the culture medium could occur, and in the case of chemical products, a more prolonged action time is recommended.

The $99.96 \%$ effectiveness of the natural extract based on Neem leaves in concentrations of 3,4 , and $5 \%$ coincides with similar studies on Staphylococcus aureus isolated from cows milk with subclinical mastitis, where Giraldo (18) pointed out an 83\% bacteriostatic activity of Neem extracts at a $5 \%$ concentration.

Valle (19) stated that the Neem leaf infusion is $100 \%$ effective against Oxyuris equi, at $15 \%$ 
concentration when used in oral administration of $60 \mathrm{ml}$. On the other hand, according to Dublin, Roque, and Estrada (20), several applications of Neem were required to achieve adequate effectiveness as an anthelmintic. Additionally, the treatments must be repeated to achieve cumulative effects, more significant bioactivity of the extract against bacteria Staphylococcus epidermidis and Stenotrophomonas maltophilia. In particular, those last emerging opportunistic pathogens with evidence of intrahospital transmission are resistant to multiple drugs and disinfectants, associated with their high mutagenic capacity $(21,22)$.

Likewise, in the study carried out by Vásquez (23), it was observed that the seed has a $40 \%$ bacterial inhibition and the leaves a 70\%. Regarding S. epidermidis, it was $60 \%$, and there was no inhibition of S. aureus and E. coli. Unlike the current study, Neem leaf's aqueous extract inhibited $S$. aureus $(99.96 \%)$ and did not inhibit S. epidermidis. Variability in fact, according to the part of the plant used, indicatesd the need to standardize the extraction process to regulate the biocidal effect of the oil.

Similarly, López et al. (24) evaluated the microbicidal activity of acetonic, ethanolic and methanolic extracts of Neem seeds, at concentrations of 1,10, 25 and 50\%, against Escherichia coli, Staphylococcus aureus, and the Bacteriophage P22, using two contact times (2.5 and $5 \mathrm{~min}$ ), reporting that the $10 \%$ ethanolic extract of Neem, inhibited the growth of E. coli. In comparison, the methanolic and acetonic extracts did so from the concentration of $25 \%$ and $50 \%$, respectively, while the Neem extracts did not achieve a total reduction of $S$. aureus. This contrasting result may be due to the reduced contact time since the $S$. aureus inhibition was 15 minutes in the current study.

\section{CONCLUSIONS}

In this research, it was evidenced that the aqueous Neem extract has biocidal properties against bacteria associated with IAAS, which indicates its potential as an active ingredient of products for hospital use. To improve the Neem extract's effectiveness, a phytochemical study and standardization of contact times for evaluation in a combined way on hospital surfaces are necessary.

Nevertheless, given the non-total effectiveness of any of the evaluated products, the combined use of them in a disinfection plan to control bacteria associated with IAAS is recommended.

\section{CONFLICT OF INTERESTS}

The authors affirm that they have no conflict of interest with the publication of the results.

\section{ACKNOWLEDGMENTS}

The authors thank the University of Santander for facilitating the execution of this project.

\section{CONTRIBUTION OF THE AUTHORS}

Hedilka Jiménez participated in the identification of bacteria associated with IAAS, Bertilda Pedraza prepared the neem extract, Jeraldin Castrillon and Aylin performed the sampling and biocidal test, Aslenis Melo performed the analysis of biocidal test data. All authors participated in the writing of the manuscript.

\section{REFERENCES}

1. Ministerio de salud y protección social. Programa de prevención, vigilancia y control de infecciones asociadas a la atención en salud-IAAS y la resistencia antimicrobiana. [Internet]. Bogotá Colombia: 2018. [cited 2020 Nov 20]. Available in: https://www. minsalud.gov.co/sites/rid/Lists/BibliotecaDigital/RIDE/VS/PP/ PAI/programa-iaas-ram.pdf

2. Rodríguez R, Bustillo D, Caicedo D, Cadena D, Castellanos C. Acinetobacter baumannii: patógeno multirresistente emergente. Revista de los estudiantes de medicina de la Universidad Industrial De Santander. 2016; 29(2):113-35.

3. Gómez RA. Brote de infecciones asociadas a la atención de salud. Protocolo de Vigilancia en Salud Pública[Internet]. Instituto Nacional de Salud. 2017. [cited 2020 Nov 20]. Available in: https://www.ins.gov.co/buscador-eventos/Lineamientos/ PRO\%20INFECCIONES\%20ASOCIADAS\%20A\%20LA\%20 ATENCION\%20EN\%20SALUD_.pdf

4. Ortiz J, Pineda I, Dennis R, Porras A. Costos atribuidos a las infecciones asociadas con la atención en salud en un hospital de Colombia, 2011-2015. Biomédica 2019; 39:102-12. DOI: https:// doi.org/10.7705/biomedica.v39i1.4061

5. Morales G. y García A. Fenotipos de resistencia antimicrobiana en cepas de Staphylococcus aureus aislados en un centro hospitalario de la ciudad de Valledupar. Febrero a julio de 2013. Biociencias 2013; 8 (2): 13-23.

6. Thombare M, Udugade B, Hol T, Mulik M, Pawade D. Formulation and evaluation of novel herbal hand sanitizer. Indo American Journal of Pharmaceutical Research 2015; 5 (1): 483-488.

7. Balakrishna S, Ghosh S, Yadav G, Sharma K, Ghosh S, Joshi S. Formulation, Evaluation and Antibacterial Efficiency of water-based herbal Hand Sanitizer Gel [Internet]. Biorxiv. 2018. [cited 2020 Nov 20]. Available in: https://www.biorxiv. org/content/10.1101/373928v2

8. Sujarwo W, Keim A, Caneva G, Toniolo C, Nicoletti M. Ethnobotanical uses of Neem (Azadirachta indica A.Juss.; Meliaceae) leaves in Bali (Indonesia) and the Indian subcontinent in relation with historical background and phytochemical 
propertie. J. Ethnopharmacol 2016 Ago 2; 189: 186-193. DOI: https://doi.org/10.1016/j.jep.2016.05.014

9. Kumari D, Shenoyb S, Khijmatgara S, Chowdhuryc A, Lynchd E, Chowdhurya Ch. Antibacterial activity of new atraumatic restorative treatment materials incorporated with Azadirachta indica (Neem) against Streptococcus mutans. Journal of Oral Biology and Craniofacial Research 2019; 9: 321-325. DOI: https://10.1016/j.jobcr.2019.06.014

10. Islas J, Acosta E, Buentello Z, Delgado J, Moreno M, Escalante $\mathrm{B}$, Moreno J. An overview of Neem (Azadirachta indica) and its potential impact on health. Journal of Functional Foods 2020; 74:104171. DOI: https://doi.org/10.1016/j.jff.2020.104171

11. Kharwar R, Sharma V, Mishra A, Kumar J, Singh1 D, Verma1 S, Gond S, Kumar A, Kaushik N, Revuru B, Kusari S. Harnessing the phytotherapeutic treasure troves of the ancient medicinal plant Azadirachta indica (Neem) and associated endophytic microorganisms. Planta Med 2020; 86: 906-940. DOI: https:// doi.org/10.1055/a-1107-9370

12. Farjana A, Zerin N, Kabir S. Antimicrobial activity of medicinal plant leaf extracts against pathogenic bacteria. Asian Pac J Trop Dis 2014; 4(Suppl 2): S920-S923. DOI: https://doi.org/10.1016/ S2222-1808(14)60758-1

13. Baildya N, Khan A, Ghosh N, Dutta T, Chattopadhyay A. Screening of potential drug from Azadirachta Indica (Neem) extracts for SARS-CoV-2: An insight from molecular docking and MD-simulation studies.2020; 18. DOI: https://doi. org/10.1016/j.molstruc.2020.129390

14. Barrabí M. y García J. Actividad antihelmíntica in vitro de extracto acuoso de hojas y semillas de Neem (Azadirachta indica A. Juss). I. Inhibición de la eclosión de huevos y del desarrollo larvario. Rev. Salud Anim 2013 May-Ago; 35(2):103-108.

15. Ortega M, Tofiño A, Mena O, Martínez M, Galvis D, Merini L. Microbial activity of essential oils of Lippia alba and Cymbopogon citratus on Streptococcus mutans and cytotoxicity in cho cells. Vitae 2016; 23 (Supl. 1): 503. DOI: https://doi.org/10.1016/j. jep.2016.10.044

16. Galván R, Ruiz R, Segura E, Cortés R. Comparative study on the effectiveness of $6 \%$ sodium hypochlorite solution vs a bromine-chloro-dimethylhydantoin solution for disinfecting hospital environments. Perinatología y Reproducción Humana. 2016 Oct; 30: 145-50. DOI: https://doi.org/10.1016/j. rprh.2017.06.001

17. Nishibori A, Kusaka J, Hara H, Umeda M, Matsumoto K. Phosphatidylethanolamine Domains and Localization of Phospholipid Synthases in Bacillus subtilis Membranes. J Bacteriol, 2005 Mar;187 (6): 2163-2174. DOI: https://doi. org/10.1128/jb.187.6.2163-2174.2005

18. Giraldo S. Efecto inhibitorio de extractos de Neem sobre cepas de Staphylococcus aureus aisladas de leche de vacas con mastitis subclínica. [Trabajo de grado de maestría en Microbiology]. [Maracaibo, Venezuela]: 2010. 106 p.

19. Valle A. Eficacia de la infusión de la hoja de Neem Azadirachta indica administrado por vía oral para el control de Oxyuris equi en caballos. [Trabajo de grado de Med Vet]. [Guatemala]: Universidad De San Carlos De Guatemala: 2011. 38 p.

20. Dublín R, Roque E y Estrada J. Eficacia del extracto de las hojas del Neem Azadirachta indica A. Juss en el control de nematodos gastrointestinales en ovino Pelibuey. Redved 2012 Jul; 13(7):1-16

21. Gröschel MI, Meehan CJ, Barilar I, Diricks M. The global phylogenetic landscape and nosocomial spread of the multidrugresistant opportunist Stenotrophomonas maltophilia. BioRxiv. 2019 Ago (28); 45 . DOI: https://doi.org/10.1038/s41467-02015123-0

22. Charoenlap N, Jiramonai L, Chittrakanwong J. et al. Inactivation of ahpC renders Stenotrophomonas maltophilia resistant to the disinfectant hydrogen peroxide. Antonie van Leeuwenhoek. 2019 Mayo; 112 (5): 809-14. DOI: https://doi. org/10.1007/s10482-018-1203-9

23. Vásquez A. Utilización del extracto alcohólico de Azadirachta indica A. Juss contra las bacterias de importancia médica Escherichia coli, Staphylococcus aureus y Staphylococcus epidermidis. Minerva Revista en línea CIC-UES 2007; 1:10

24. López, Y, et al. Efecto antimicrobiano de extracto de Neem (Azadirachta indica A. juss) y nevadillo (Swietenia humilis Zucc) contra E.coli, S. aureus y el bacteriófago P22. Bioquímica 2007 Oct-Dic; 32: 117-35 